\title{
PERANCANGAN APLIKASI MONITORING PENELITIAN DAN PENGABDIAN MASYARAKAT INTERNAL PERGURUAN TINGGI
}

\author{
Gerlan Apriandy Manu ${ }^{1}$, Ellen Tantrisna ${ }^{2}$ \\ ${ }^{1,2}$ Universitas Citra Bangsa, Prop Nusa Tenggara Timur \\ 1.gerlan.manu@gmail.com, ${ }^{2}$ st.f4nny@gmail.com
}

\begin{abstract}
ABSTRAK
Penelitian ini bertujuan untuk menghasilkan sebuah sistem yang dapat memanajemen kegiatan Penelitian dan Pengabdian Masyarakat di Lingkup Internal Perguruan Tinggi dengan studi kasus pada Universitas Citra Bangsa. Untuk menjamin tercapainya target penelitian dan pengabdian masyarakat pada suatu Perguruan Tinggi perlu dilakukan monitoring dan evaluasi secara berkesinambungan oleh Lembaga Penelitian, Pengembangan dan Pengabdian kepada Masyarakat (LP3M) atau sejenisnya. Kegiatan monitoring perlu ditunjang dengan adanya aplikasi atau sistem manajemen pada setiap Perguruan Tinggi. Penelitian ini membahas tentang perancangan arsitektur sistem, rancangan basis data, rancangan sistem, serta proses bisnis penggunaan sistem.
\end{abstract}

Kata kunci : SIMLITABMAS, Monitoring, Rancang Bangun Sistem, PHPMaker

\section{ABSTRACT}

This study purpose to produce a management system that can manage Research and Community Service activities in the Internal College with a case study at Citra Bangsa University. To ensure the accomplished of research and community service targets at a college, it is necessary to continuous monitoring and evaluation by the Institute for Research, Development and Community Service (LP3M) or other similar institutions. Monitoring activities need to be supported by the application or management system at each university. This study discusses about system architecture design, database design, system design, and business processes of system use.

Keywords: SIMLITABMAS, Monitoring, System Design, PHPMaker

\section{PENDAHULUAN}

Pendidikan merupakan suatu proses pengembangan Sumber Daya Manusia (SDM) untuk meningkatkan potensi diri peserta didik yang memiliki kekuatan spiritual keagamaan, pengendalian diri, kepribadian, kecerdasan, akhlak, ilmu dan keterampilan. Melalui pendidikan suatu bangsa atau negara dapat menyiapkan rakyatnya untuk mampu bersaing dengan bangsa atau negara lainnya dalam persaingan global saat ini. Di Indonesia tujuan dari pendidikan diatur dalam Undang-Undang Sistem Pendidikan Nasional yakni Nomor 20 tahun 2003 pasal 3. Perguruan Tinggi adalah salah satu lembaga yang berperan dalam Pendidikan. Perguruan Tinggi dituntut untuk menghasilkan Sumber Daya Manusia (SDM) yang bermutu guna memenuhi kebutuhan pembangunan bangsa atau Negara. Salah satu tujuan yang harus dicapai dan dilakukan di Perguruan Tinggi adalah Tri Dharma Perguruan Tinggi. Tri 
Dharma Perguruan Tinggi yaitu 1) Pendidikan dan Pengajaran, 2) Penelitian dan Pengembangan, dan 3) Pengabdian Kepada Masyarakat. Penelitian dan Pengabdian kepada Masayarakat yang merupakan bagian dari Tridarma perguruan tinggi (PT) selain melaksanakan Pendidikan sebagaimana diamanahkan oleh Undang-undang Nomor 20 Tahun 2003 tentang Sistem Pendidikan Nasional Pasal 20 [3].

Penelitian didefinisikan oleh Howard and Sharp (dalam Bell (1993:2) mengatakan: research as seeking through methodological process to add to one's own body of knowledge and hopefully, to that of others, by the discovery of non-trivial facts and insights. Selanjutnya Drew (1980) dalam Bell (1993:2) yang mengatakan bahwa : research is conducted to solve problems and to expand knowledge and he stresses that research is a systematic way of asking questions, a systematic method of enquiry [2]. Dengan demikian, penelitian harus dikerjakan menurut kaidah dan metode ilmiah/keilmuan (scientific research) secara obyektif, logis dan sistematis. Selain penelitian dalam suatu disiplin ilmu tertentu, penelitian juga dapat dilakukan dengan melibatkan berbagai ilmu atau inter-disiplin.

Secara umum Pengabdian Kepada Masyarakat terdiri atas dua jenis yaitu Kegiatan Pengabdian Kepada Masyarakat yang berbasis pada Penelitian, dan yang bersifat Reguler. Kegiatan Pengabdian Kepada Masyarakat yang berbasis pada Penelitian yaitu kegiatan Kegiatan Pengabdian Kepada Masyarakat yang mengimplementasikan hasil-hasil penelitian baik yang berorientasi pada masyarakat secara umum, industri, instansi pemerintah dan lingkungan internal perguruan tinggi tersebut. Sedangkan Kegiatan Pengabdian Kepada Masyarakat yang bersifat Internal yaitu kegiatan Pengabdian kepada Masyarakat yang tidak harus merupakan implementasi hasil-hasil penelitian. Kegiatannya dapat meliputi pelatihan-pelatihan, penyulusan atau sosialisasi, pemberdayaan masyarakat, pembinaan unit usaha dan kegiatan lain yang memberikan manfaat bagi masyarakat berdasarkan kompetensi yang dimiliki oleh perguruan tinggi.

Untuk menjamin tercapainya target penelitian dan pengabdian masyarakat pada suatu Perguruan Tinggi perlu dilakukan monitoring dan evaluasi secara berkesinambungan. Direktorat Riset dan Pengabdian Masyarakat - DRPM berperan sebagai fasilitator, penguat, dan pemberdaya berupaya terus mengawal penelitian dan pengabdian kepada masyarakat di perguruan tinggi. Terdapat beberapa program pendanaan penelitian juga pengabdian masyarakat yang diselenggarakan oleh DRPM. Ketua Peneliti dan Ketua Tim Pelaksanaan Kegiatan Pengabdian pada Masyarakat dapat mengusulkan proposal penelitian atau proposal abdimas pada Sistem Informasi Manajemen Penelitian dan Pengabdian kepada Masyarakat - SIMLITABMAS yang dapat diakses pada http://simlitabmas.ristekdikti.go.id [7]

Dengan SIMLITABMAS, kegiatan Penelitian dan Pengabdian pada Masyarakat yang didanai oleh DRPM dapat dilakukan monitoring dan evaluasi dengan baik. Setiap Ketua Peneliti dan Ketua Tim Pelaksanaan Kegiatan Abdimas wajib 
melaporkan proses kegiatan, penggunaan dana, hingga pada publikasi jurnal hasil dari penelitian atau abdimas yang dilakukan.

Kegiatan Monitoring dan Evaluasi terhadap Kegiatan Penelitian atau Kegiatan Abdimas juga perlu dilakukan oleh Internal Perguruan Tinggi, baik kegiatan yang didanai oleh DRPM, didanai Perguruan Tinggi, maupun didanai secara mandiri oleh Tim Peneliti dan Tim Adbimas. Oleh karena itu setiap Lembaga Perguruan Tinggi wajib memiliki suatu Sistem Informasi Manajemen Penelitian dan Pengabdian kepada Masyarakat SIMLITABMAS sendiri. Sehingga dalam penelitian ini dibahas mengenai rancangan pengembangan Sistem Informasi Manajemen Penelitian dan Pengabdian kepada Masyarakat - SIMLITABMAS Internal Perguruan Tinggi menggunakan PHPMaker 2020.

PHP Code Generator adalah sebuah program yang dibuat khusus untuk dapat menghasilkan intruksi atau kode PHP secara terstruktur mengikuti suatu framework PHP tertentu. Seorang pengembang sistem (programmer) dapat membuat suatu sistem tanpa perlu melakukan coding. Source code PHP akan terbentuk secara otomatis sesuai dengan konfigurasi yang sebelumnya telah diatur oleh programmer. Dengan ini dapat mempersingkat waktu pengerjaan sistem dengan melewati tahap mencari atau memperbaiki jika terjadi error code.

Terdapat beberapa PHP Code Generator antara lain CRUDigniter, PHP Maker, Vemto, dbQwikSite, PHP Generator for MySQL, PHP-Peanuts, WizzyWeb dan sebagainya. Beberapa PHP Code Generator bersifat gratis dan berbayar. Dengan menggunakan PHP Code Generator ini, seorang pengembang sistem tidak memerlukan keterampilan pemrograman yang tinggi. Yang diperlukan adalah keterampilan penggunaan web server, dan database server dengan baik

PHPMaker adalah sebuah aplikasi yang dapat menghasilkan kode PHP untuk membuat suatu sistem berbasis web dengan mudah dan cepat. PHPMaker menyediakan akses untuk koneksi database, pengaturan tampilan (interface) sistem, pengaturan menu, pengaturan webmail, pengaturan keamanan sistem, dan lain sebagainya. PHPMaker akan menghasilkan sebuah halaman web berupa list page atau halaman berisi daftar data yang ada pada tabel, add/copy form atau halaman formulir tambah data atau salin data, view page atau halaman melihat suatu record data, edit page atau halaman formulir edit data, delete page atau perintah menghapus data, search page atau halaman pencarian data berdasarkan kolom tertentu, page number data pada tabel dapat dilihat dalam nomor halaman tertentu, export - memungkinkan data tabel dapat diekpor menjadi file pdf, doc, excel, dan lain sebagainya, import memungkinkan data dapat dimasukkan ke dalam sistem melalui file excel. PHPMaker juga dapat menghasilkan halaman berisi chart atau diagram. PHPMaker dapat diperoleh pada laman https://phpmaker.dev/download.php [8] saat ini terdapat PHPMaker terbaru yaitu PHPMaker 2020 dengan beberapa kelebihan fitur dibanding versi sebelumnya.

\section{METODE PENELITIAN}

Pada penelitian ini menggunakan metode penelitian SDLC (Systems 
Development Life Cycle) atau Siklus Hidup Pengembangan Sistem. Tahap-tahap penelitian menurut SDLC adalah sebagai berikut :

\section{Planning (Perencanaan)}

Peneliti melakukan observasi langsung dan wawancara terhadap Ketua LP3M Universitas Citra Bangsa, Staf LP3M dan beberapa dosen Universitas Citra Bangsa. Dari hasil observasi dan wawancara ini ditemukan beberapa faktafakta yang menjadi latar belakang permasalahan manajemen Penelitian dan Pengabdian Masyarakat Internal Perguruan Tinggi di Lingkup Universitas Citra Bangsa.

\section{Analysis (Analisis)}

Berdasarkan fakta-fakta yang ditemukan maka peneliti dapat melakukan beberapa analisis yaitu: Analisis Teknologi dan Analisis Informasi.

\section{a. Analisis Teknologi}

i.Universitas Citra Bangsa sudah memiliki sistem manajemen yang dapat diakses pada laman http://cyberchmk.net/lpm. Dosen dan LP3M dapat menggunakan sistem ini untuk melaporkan proses kegiatan penelitian dan pengabdian masyarakat di lingkup Universitas Citra Bangsa. Namun terdapat beberapa kekurangan sistem seperti, dosen dapat mengubah dan menghapus masukan data ke sistem yang dimasukkan oleh dosen lain. Sistem tidak dapat memberikan laporan per tahun atau per semester terkait jumlah penelitian atau pengabdian masyarakat yang dilaporkan dosen per masing-masing program studi. Sistem kurang user friendly - sehingga tidak semua dosen berpartisipasi dalam menambah data. ii. Diperlukan database MySQL yang akan digunakan untuk menyimpan data arsip yang diunggah. Database MySQL dapat diakses secara online oleh LP3M, Dosen dan user lain yang berkepentingan.

iii. Diperlukan pembuatan Sistem Informasi Manajemen yang baru menggantikan sistem yang lama dengan melengkapai kekurangan yang ada sebagai interface sistem yang juga dapat diakses secara online oleh setiap jenis user yang berkepentingan.

\section{b. Analisis Informasi}

i.Diperlukan Data Dosen per Program Studi, Data Penelitian dan Data Pengabdian Masyarakat yang pernah dimasukkan ke sistem yang lama.

ii. Diperlukan SOP Manajemen Penelitian dan Pengabdian Masyarakat lingkup Universitas Citra Bangsa

iii. Diperlukan Data Penelitian dan Pengabdian Masyarakat sebagai contoh data dalam pengujian sistem.

\section{Design (Desain)}

Pada tahap ini peneliti melakukan Desain Sistem dengan menggunakan Model DFD (Data Flow Diagram) dan desain Database yang digambarkan dengan Deskripsi Tabel dan Relasi Tabel.

\section{Implementation (Implementasi)}

Pada tahap ini peneliti mulai melakukan pengkodean (coding) dengan menggunakan Bahasa Pemrograman PHP untuk membuat Sistem Efilling berdasarkan Model DFD yang sudah dirancang sebelumnya. Dan peneliti juga membuat Database MySQL sesuai dengan desain Database yang telah dirancang pada 
tahap sebelumnya. Dalam pengkodean peneliti menggunakan PHPMaker 2020 untuk proses pengkodean dengan waktu yang singkat dan hasil kode php yang maksimal.

\section{Testing (Pengujian)}

Pada tahap ini peneliti melakukan percobaan memasukan data contoh, dan menguji semua alur sistem yang sudah dibuat pada tahap implementasi. Jika ditemukan kesalahan pengkodean (error/bug) ataupun kesalahan logika maka akan kembali ke tahap sebelumnya yaitu tahap desain dan implementasi.

\section{Maintenance (Perawatan)}

Merupakan tahap akhir dalam pengembangan sistem. Perawatan atau Maintenance akan dilakukan jika sistem sudah digunakan oleh pengguna sistem (user), akan dilakukan perbaikan jika masih ditemukan kesalahan pengkodean (error/bug).

\section{HASIL DAN PEMBAHASAN}

\section{Arsitektur Sistem}

Berikut adalah Arsitektur Sistem SIMLITABMAS Internal Universitas Citra Bangsa :

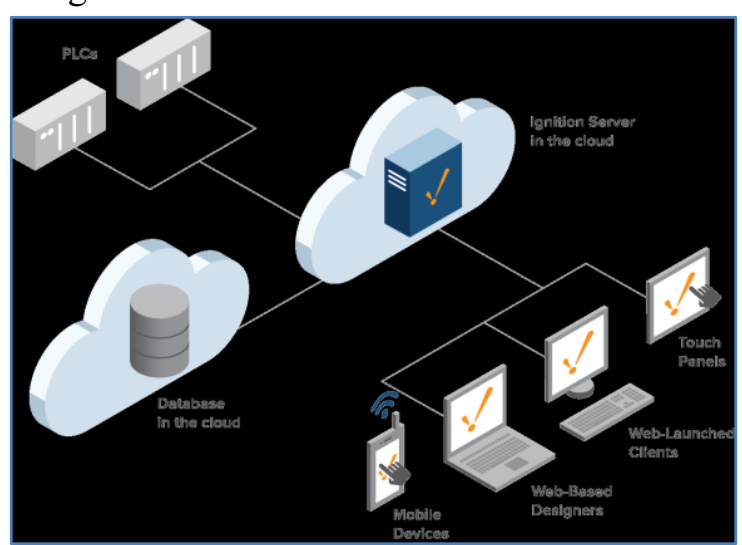

Gambar 1. Arsitektur Sistem

Rancangan Sistem ini menggunakan DFD (Data Flow Diagram). Dalam perancangan
DFD dapat digambarkan Diagram Berjenjang, Diagram Konteks dan Diagram Level 0 dan level selanjutnya. DFD ini adalah salah satu alat pembuatan model yang sering digunakan, khususnya bila fungsi-fungsi sistem merupakan bagian yang lebih penting dan kompleks dari pada data yang dimanipulasi oleh sistem [6].

Berikut adalah Bagan berjenjang yang menggambarkan proses sistem yang berjalan setiap levelnya :

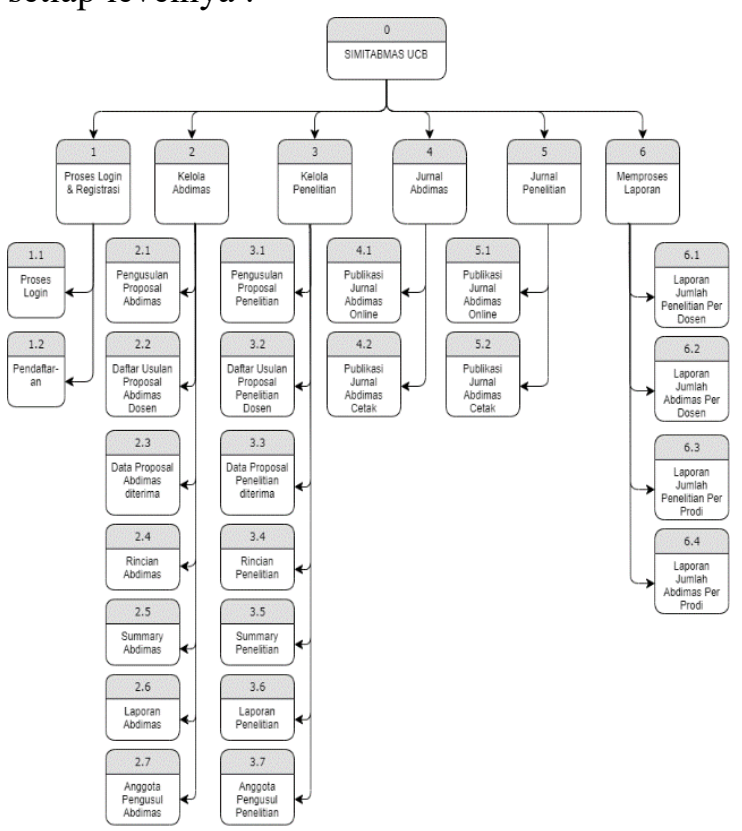

Gambar 2. Bagan Berjenjang

Dapat dilihat pada gambar 2. Bagan Berjenjang terdapat 6 proses utama dalam sistem yaitu Proses Login \& Register, Proses Kelola Abdimas, Proses Kelola Penelitian, Proses Kelola Jurnal Penelitian, Proses Kelola Jurnal Abdimas, dan Proses Laporan

\section{DFD Level 0}

Berikut adalah gambar DFD Level 0 berdasarkan gambar Bagan Berjenjang diatas (Gambar 2) : 


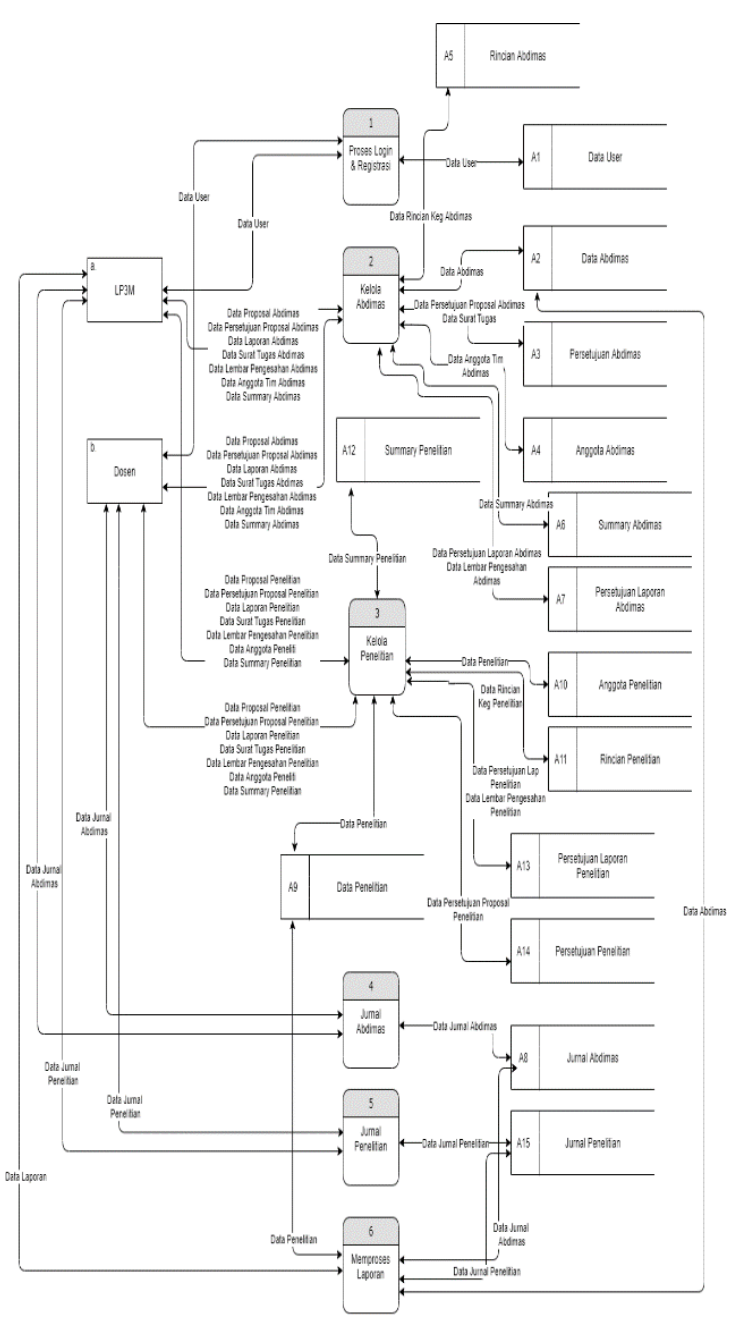

Gambar 3. Diagram Level 0

Pada gambar 3. Diagram Level 0 diatas digambarkan tentang alir data yang berjalan dalam 6 proses utama sistem, terdapat dua jenis user yaitu LP3M dan Dosen. Masing-masing jenis user memiliki hak akses tersendiri. Dosen dalam melakukan manajemen terhadap penelitian, dan abdimas yang dilakukannya sendiri dalam suatu tim. Dan LP3M memiliki akses untuk manajemen keseluruhan penelitian dan abdimas yang dilakukan oleh semua dosen.

\section{Relasi Tabel}

Berikut adalah gambar relasi tabel :

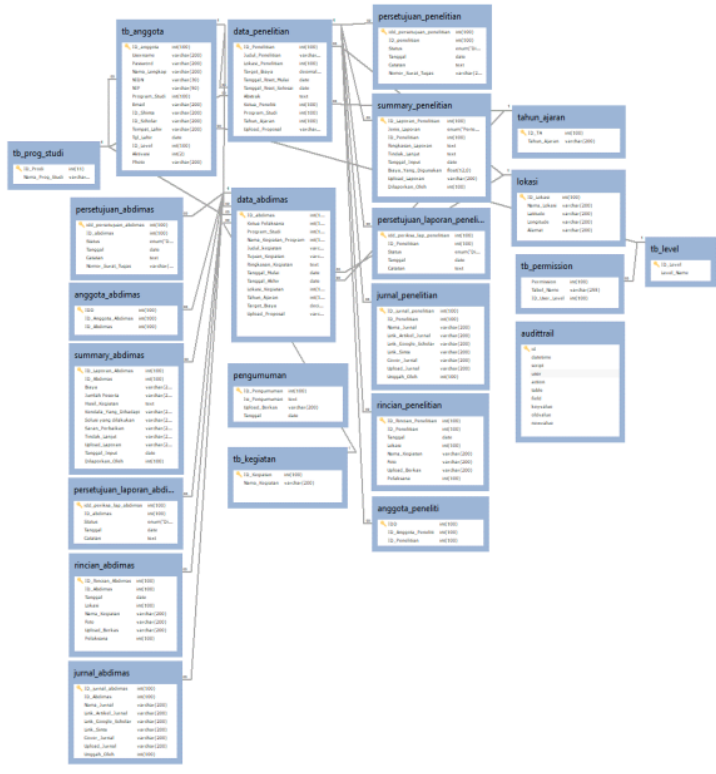

Gambar 4. Relasi Tabel

Pada gambar 4. Relasi Tabel dijelaskan tentang hubungan antara tabel yang digunakan dalam database sistem. Basis data sistem ini dibangun menggunakan MySQL DBMS. MySQL merupakan suatu server database yang membantu pengolahan basis data dengan sangat cepat menggunakan SQL Language. [1]. MySQL bersifat open source dan merupakan salah satu software database yang banyak digunakan [5].

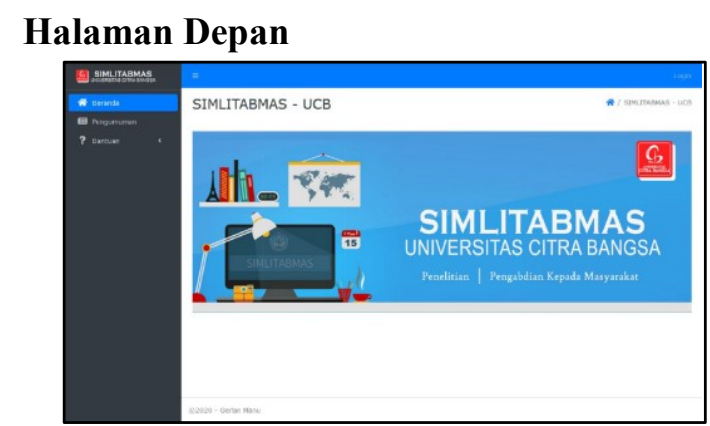

Gambar 5. Halaman Utama Sistem

Pada gambar 5 diatas dapat dilihat halaman utama sistem, terdapat menu Login, Beranda, Pengumuman, dan Bantuan. Menu Login akan mengarahkan ke halaman login, halaman beranda, menampilkan gambar utama (header), Menu Pengumuman untuk mengarah ke 
halaman pengumuman yang berisikan pengumuman terkait dengan Penelitian dan Abdimas yang berlangsung di lingkungan Universitas Citra Bangsa. Menu Bantuan berisikan panduan penggunaan sistem.
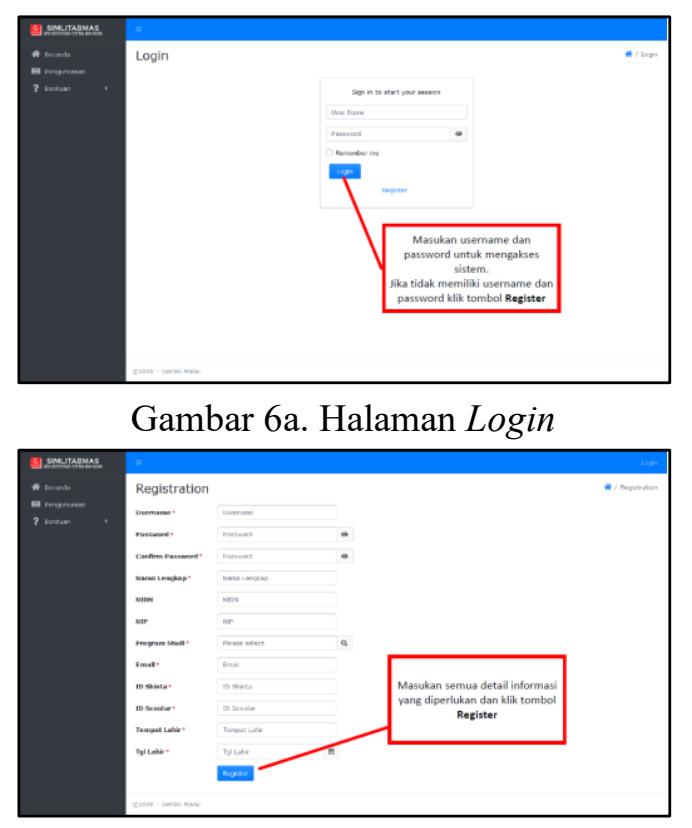

Gambar 6b. Halaman Register

Pada halaman login, berisikan form login yang digunakan untuk masuk ke dalam sistem (Gambar 6a), sedangkan halaman register untuk dosen yang belum terdaftar dalam sistem perlu melakukan pendaftaran atau register terlebih dahulu (Gambar 6b).

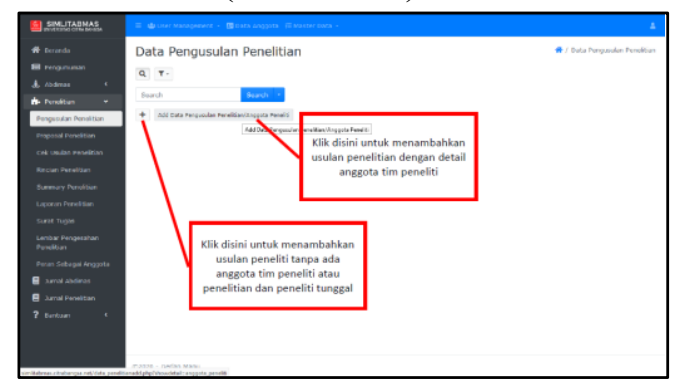

Halaman 7. Pengusulan Penelitian oleh Dosen

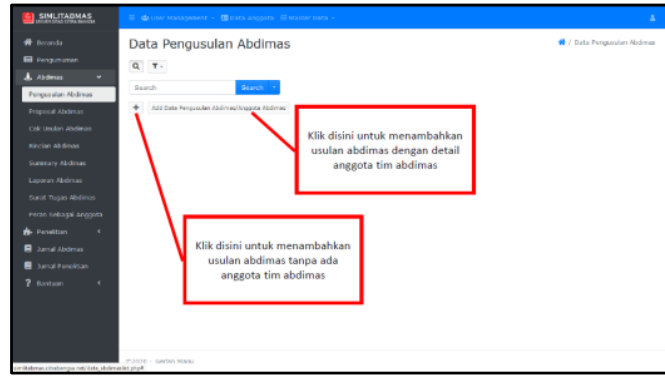

Gambar 8. Pengusulan Kegiatan Abdimas oleh Dosen

Pada gambar 7, Dosen dapat menambahkan data usulan penelitian yang nantinya akan diproses oleh LP3M untuk disetujui usulannya atau ditolak atau revisi. Setelah usulan diterima, dosen dapat menambahkan proses kegiatan penelitian yang dilakukan pada menu Rincian Penelitian dan pada akhir penelitian dosen wajib menambahkan data Laporan Akhir Penelitian pada menu Summary Penelitian. Data laporan akhir akan ditinjau oleh LP3M dan akan diberikan Lembar Pengesahan untuk dapat diunduh oleh Dosen dan dicetak kemudian di tandatangani oleh Dosen sebagai Ketua Peneliti, disahkan oleh Ketua LP3M mengetahui Rektor.

Pada gambar 8, Setiap Dosen yang berperan sebagai Ketua Abdimas melakukan pengusulan abdimas melalui SIMLITABMAS UCB kemudian akan dilakukan persetujuan pengusulan oleh LP3M UCB jika form usulan penelitian telah terisi dengan lengkap dan benar. Setelah status usulan penelitian diterima atau disetujui oleh LP3M UCB, barulah Surat Tugas dapat diakses dan dicetak oleh Ketua Abdimas. Selanjutnya dalam sistem, Ketua Abdimas atau Anggota Abdimas dapat menambahkan catatan atau rincian kegiatan Abdimas yang dilakukan selama masa kegiatan Abdimas dilakukan. Pada rincian Kegiatan Abdimas diunggah juga foto-foto kegiatan Abdimas yang dilakukan dilengkapi dengan tanggal kegiatan abdimas dan lokasi kegiatan dilakukan. Pada akhir Kegiatan Abdimas, Ketua Abdimas perlu menambahkan data 
summary Abdimas dan mengunggah laporan akhir abdimas. Setelah Laporan Akhir diunggah dan disetujui oleh LP3M barulah Ketua Abdimas dapat mengakses dan mencetak Lembar Pengesahaan Abdimas, sebagai bukti berakhirnya proses kegiatan Abdimas tersebut.

Pada kegiatan penelitian ataupun abdimas dimulai dengan pengusulan proposal kegiatan. Tanpa pengusulan proposal kegiatan tersebut, data penelitian atau abdimas yang dilakukan dosen baik didanai oleh Kemenristekdikti, Yayasan, Perguruan Tinggi, atau Mandiri tidak akan tercatat dalam sistem. Menurut Gaol, sistem adalah hubungan satu unit dengan unit lainnya, satu unit macet/terganggu, unit lainnya pun akan terganggu untuk mencapai tujuan yang telah ditetapkan tersebut [4]. Sistem ini pun demikian LP3M yang bertugas untuk memanajemen kegiatan penelitian dan abdimas yang dilakukan dosen, dapat melihat data rangkuman penelitian dan abdimas pada sistem jika dosen memasukkan data penelitian atau abdimasnya melalui standar proses penggunaan sistem yang telah ditetapkan.

\section{KESIMPULAN}

Berdasarkan penelitian
$\begin{aligned} & \text { yang } \\ & \text { dilakukan maka peneliti }\end{aligned}$
menyimpulkan beberapa hal
berikut :

1. SIMLITABMAS Internal Perguruan Tinggi dapat berfungsi sebagai sistem monitoring penelitian dan pengabdian masyarakat yang dilakukan oleh dosen pada suatu perguruan tinggi tertentu.

2. SIMLITABMAS UCB ini hanya dapat diakses oleh Dosen dan LP3M Universitas Citra Bangsa.

3. SIMLITABMAS UCB ini memiliki 2 level pengguna yaitu Administrator (LP3M), dan Dosen. Administrator (LP3M) memiliki akses keseluruhan sistem, sedangkan Dosen memiliki akses terbatas, mengelola proses kegiatan penelitian atau pengabdian masyarakat yang dilakukan.

4. SIMLITABMAS UCB ini dibuat dengan menggunakan PHPMaker 2020, yang dapat mempersingkat masa pengerjaan coding system.
5. SIMLITABMAS
UCB
ini menggunakan Database MySQL.

\section{DAFTAR PUSTAKA}

[1] Agus Saputra, 2011, Panduan Praktis Menguasai Database Server MySQL. Jakarta : PT. Elex Media Komputindo.

[2] Bell, B.F. 1993. Children's Science, Constructivism and Learning in Science. Victoria : Deakin University

[3] Depdiknas. 2003. Undang-Undang Republik Indonesia No.20 tahun 2003 tentang Sistem Pendidikan Nasional

[4] Gaol, L, Jimmy. 2008. Sistem Informasi Manajemen Pemahaman dan Aplikasi. Jakarta : Penerbit PT Grasindo.

[5] Heni A. Puspitosari. 2011. Pemrograman Web Database dengan PHP \& MySQL. Yogyakarta : Skipta Media Creative.

[6] Jogiyanto. 2005. Analisis \& Desain Sistem Informasi: Pendekatan Terstruktur, Teori dan Praktik Aplikasi Bisnis. Yogyakarta: CV Andi Offset.

[7] Simlitabmas : Sistem Informasi Manajemen Penelitian dan Pengabdian kepada Masyarakat http://simlitabmas.ristekdikti.go.id diakses tanggal 02 september 2020

[8] PHPMaker 2020 - The Best PHP Code Generator https://phpmaker.dev diakses tanggal 02 september 2020 